\title{
Comparative Study of Chemically and Mechanically Activated Clay Pozzolana
}

\author{
James Sarfo-Ansah $^{1}$, Eugene Atiemo ${ }^{1}$, Kwabena Appiah Boakye ${ }^{1}$, Zsuzsanne Momade ${ }^{2}$ \\ ${ }^{1}$ Building Material Development Division, Building and Roads Research Institute, Council for Scientific and Industrial Research, \\ Kumasi, Ghana; ${ }^{2}$ Department of Chemical Engineering, Kwame Nkrumah University of Science and Technology, Kumasi, Ghana. \\ Email: abeefo@yahoo.com
}

Received December $10^{\text {th }}, 2013$; revised January $16^{\text {th }}, 2014$; accepted January $29^{\text {th }}, 2014$

Copyright (c) 2014 James Sarfo-Ansah et al. This is an open access article distributed under the Creative Commons Attribution License, which permits unrestricted use, distribution, and reproduction in any medium, provided the original work is properly cited. In accordance of the Creative Commons Attribution License all Copyrights (C) 2014 are reserved for SCIRP and the owner of the intellectual property James Sarfo-Ansah et al. All Copyright (C) 2014 are guarded by law and by SCIRP as a guardian.

\section{ABSTRACT}

Burnt clay pozzolana produced from a clay deposit at Mankranso in Ghana has been activated by mechanical means through roll milling and ball milling as well as chemically by the addition of $1 \%-4 \% \mathbf{m} / \mathrm{m} \mathrm{Na}_{2} \mathrm{SO}_{4}$. The pozzolana sample was chemically suitable with total $\mathrm{SiO}_{2}+\mathrm{Al}_{2} \mathrm{O}_{3}+\mathrm{Fe}_{2} \mathrm{O}_{3}$ content $\geq 70 \%$ as stipulated by the ASTM C 618 standard. The particle sizes, surface characteristics and specific surface areas obtained by the types/degrees of milling were analyzed and their effect on the strength development of Portland pozzolana cement mortar cubes prepared from the pozzolana samples was evaluated. Compressive strengths obtained showed that the activated pozzolana could be used to replace up to $40 \%$ ordinary Portland cement (OPC) and satisfy the EN 197-1 and ASTM C 595 standard requirements. Comparatively, the chemically activated pozzolana cement mortars attained higher compressive strengths than the mechanically activated pozzolana cement mortars at equal ages of tests and the same pozzolana content levels. The chemically activated pozzolana cement mortars attained higher 2 day strengths than OPC at sulphate concentrations of $3 \%$ and $4 \%$ for all pozzolana content levels between $30 \%$ - 40\%. SEM image and insoluble residue in $\mathrm{HCl}$ of a 2 day old chemically activated pozzolana cement paste confirmed dissolution of fine pozzolana particles in the alkaline media which influenced higher early age strengths. The highest 28 day compressive strength of $54.2 \mathrm{MPa}$ was obtained at $4 \%$ sulphate concentration and $30 \%$ pozzolana content for the chemically activated pozzolana. The highest 28 days compressive strength for the mechanically activated pozzolana was $35.6 \mathrm{MPa}-\mathrm{obtained}$ for the roll milled product at $30 \%$ pozzolana content. Standard consistence of the pozzolana cement pastes increased with increasing pozzolana fineness and pozzolana content. Increasing $\mathrm{Na}_{2} \mathrm{SO}_{4}$ concentration however had no effect on standard consistence. Setting times decreased with increase in both fineness and sulphate concentration. The EN 197-1 standard for initial setting time was satisfied by the chemically activated pozzolana cement mortars at all pozzolana content levels. Pozzolana samples activated by roll milling and $\mathbf{3 6} \mathrm{h}$ ball milling had faster initial setting times than the EN 196-1 standard at all pozzolana content levels beyond 30\%. The ASTM C 595 requirement for initial set was however satisfied at all pozzolana content levels.

\section{KEYWORDS}

Pozzolana Cement; Mechanical Activation; Chemical Activation; Compressive Strength; Setting Time

\section{Introduction}

Cement is the most widely used construction material throughout the world with an estimated consumption of about 2.86 billion tons of Portland cement per annum worldwide [1]. Cement production is however harmful to the environment due to carbon dioxide emission. Ap- proximately 0.8 tons of $\mathrm{CO}_{2}$ is estimated to be released into the atmosphere per ton of cement produced [2]. With the cement industry accounting for 5\% - 8\% of global $\mathrm{CO}_{2}$ emission, the cement industry is the second largest producer of this greenhouse gas [3]. $\mathrm{SO}_{3}$ and $\mathrm{NOx}$ released as a result of Portland cement manufacture are 
also known to cause serious environmental problems such as greenhouse effect and acid rain [4]. Reducing cement production while maintaining sustainable development has thus been an important issue in the development of construction materials.

Replacing Portland cement with high volumes of mineral admixtures such as pozzolanas has received attention as a possible solution to the environmental challenges posed by cement manufacture [5]. Pozzolanas are materials which in themselves are non-cementitious but will react with lime at ambient temperature in the presence of moisture to form stable cementitious compounds [6]. The production and use of blended cements incorporating up to $30 \%$ of pozzolana are promulgated in many national and international standards [7-11]. One area of research being carried out worldwide is geared towards the activation of pozzolanas notably fly ash to pave the way for incorporation of higher volumes in the manufacture of blended cements [12-14]. Methods employed to activate pozzolanas include thermal [15-17]; the use of chemicals such as alkalis and sulphates to break the glassy surface silane chain [18-21] and mechanical methods-usually by the use of prolonged or fine grinding to the micrometer scale [22-24].

Research into clay pozzolanas in Ghana indicates that by replacing approximately $30 \%$ by mass of ordinary Portland cement with burnt clay pozzolana through intimate mixing, Portland pozzolana cement (PPC) with compressive strength values good for both load-bearing and non-load bearing structural applications could be produced $[25,26]$. This paper presents some properties of blended cement incorporating higher volumes of mechanically and chemically activated burnt clay pozzolana.

\section{Materials and Methods}

Calcined clay pozzolana, produced from a clay deposit located at Mankranso in Ghana was used for the research. Figure 1 shows a PHILLIPS PW 1830 XRD image of a sample of the clay. The main clay minerals identified in the clay are kaolinite and chlorite with other rock forming minerals such as quartz and goethite. Ordinary Portland cement (OPC) of class 42.5 N, meeting EN 197-1 standards, manufactured by Ghana Cement Company Limited (GHACEM) —a subsidiary of Heidelberg Cement Group was used for the research. Pit sand commonly used for construction was used as fine aggregate for making the mortar cubes. Figure 2 shows the block diagram for the production of the activated pozzolanas.

\subsection{Activation of Pozzolana}

The fired nodules were first crushed with a hammer mill to an average particle size of $80 \%$ passing a $100 \mu \mathrm{m}$ sieve and divided into three portions. One portion was reserved as the hammer mill product. The second portion of the crushed pozzolana was milled in a $1 \mathrm{~m}$ long, $30 \mathrm{~cm}$ inner diameter ball mill. Samples were taken after every $6 \mathrm{~h}$ and analyzed for significant change in the fineness as

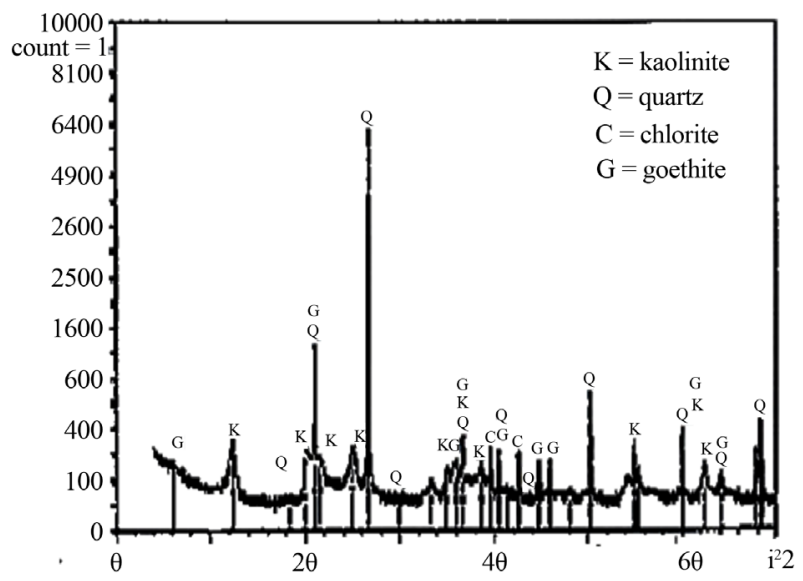

Figure 1. X-ray diffraction image of clay sample.

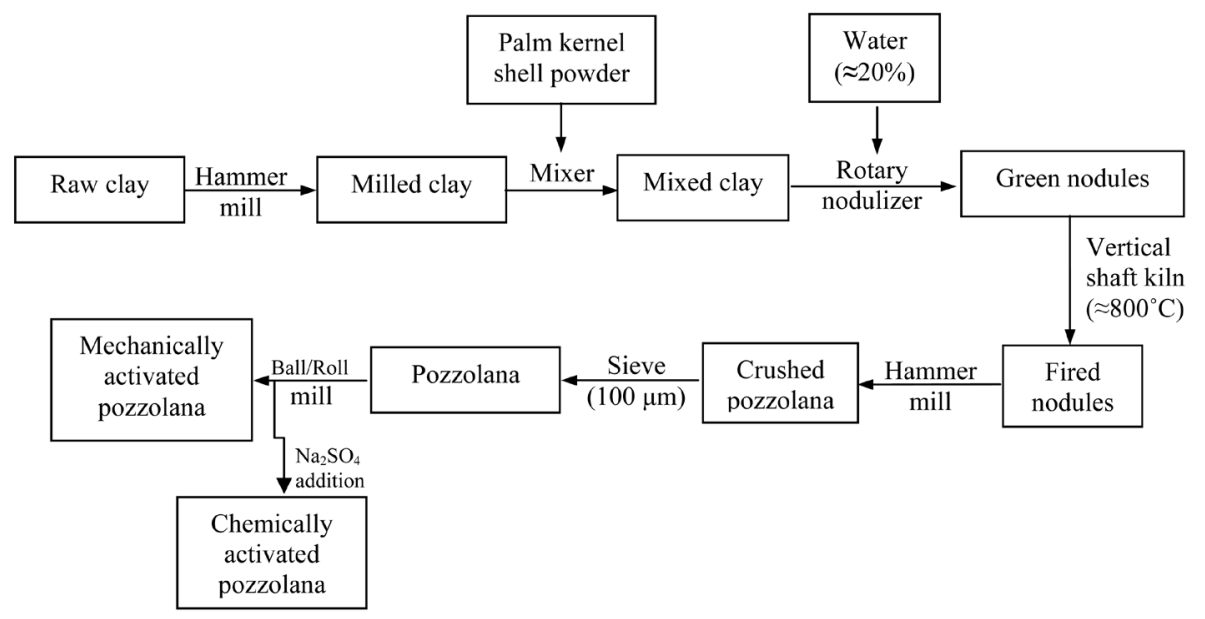

Figure 2. Block diagram of activated pozzolana production. 
determined by hydrometer sedimentation methods in BS 1377 [27]. This was continued for $24 \mathrm{~h}$. The product of the $24 \mathrm{~h}$ ball milled pozzolana was further divided into two: one part was reserved for chemical activation and the other part received further ball milling until agglomeration was observed. $1 \%$ - $4 \%$ (by mass of total cement) of reagent grade $\mathrm{Na}_{2} \mathrm{SO}_{4}$ was added to the mixing water to achieve chemical activation. The third portion of crushed pozzolana was milled in a Raymond type ringroll mill and the particle size distribution also determined

\subsection{Chemical and Physical Evaluation}

Determination of the main chemical constituents of the pozzolana was done using a SpectroXlab 2000 X-Ray Fluorescence spectrophotometer. Blaine specific surface areas of the milled pozzolana samples were determined according to the method of ASTM C 204 [28]. Compressive strengths of the blended cements containing $30 \%$, $35 \%$ and $40 \%$ of the pozzolanas were performed based on EN 196-1 [29]. The insoluble residue content of pastes determinations were based on EN 196-2 [30] whilst the setting times and standard consistencies of pastes were determined according to methods in EN 196-3 [31].The surface structure of the pozzolana powder and hydrated paste samples was studied with an Olympus BX 41 TF optical microscope and a JSM-1600 LV backscattered scanning electron microscope respectively.

\section{Results and Discussion}

\subsection{Chemical Composition}

Table 1 shows the chemical composition of the pozzolana sample and OPC. The $\mathrm{SiO}_{2}$ content of the pozzolana exceeded the minimum limit of $25.0 \%$ as prescribed by EN 197-1. The sum of $\mathrm{SiO}_{2}, \mathrm{Al}_{2} \mathrm{O}_{3}$ and $\mathrm{Fe}_{2} \mathrm{O}_{3}$ also exceeded the minimum of $70 \%$ prescribed by ASTM C 618 for the pozzolana samples. Thus the material was chemically suitable as a pozzolana. The loss on ignition was also below the maximum limit of $5.0 \%$ required of pozzolanas as specified in EN 197-1. The OPC used had a loss on ignition of $2.58 \%$ which also satisfied the maximum 3.5\% allowed by EN 197-1.

\subsection{Particle Size Classification}

Figures 3 and 4 show microscopic images of $36 \mathrm{~h}$ ball milled and roll milled pozzolana samples respectively. Rosin-Rammler distribution plots of the pozzolana samples for the various degrees and types of milling are shown in Figure 5. Most pozzolana particles were iregularly shaped after prolonged milling of $36 \mathrm{~h}$ and even by roll milling with high surface areas. There appeared to be some level of aggregation of the roll milled product. The irregular shapes and high surface areas would con-

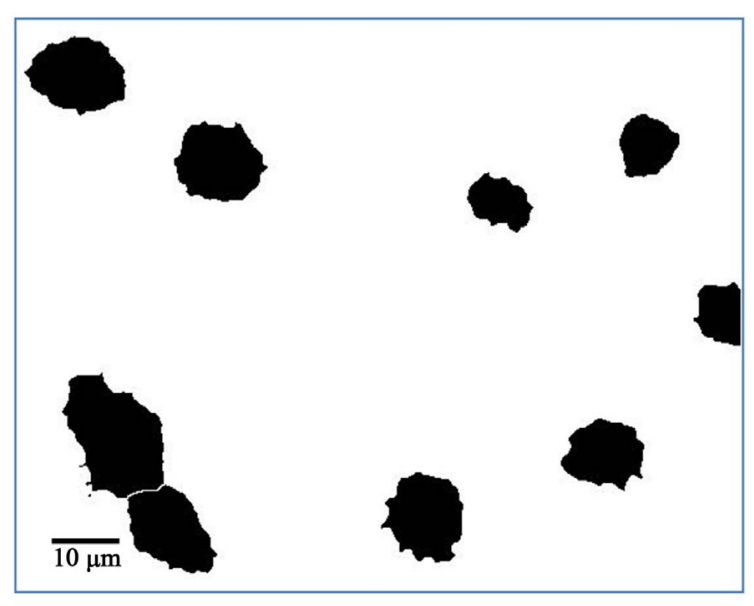

Figure 3. Optical microscope observation of $36 \mathrm{~h}$ ball milled pozzolana particles $(\times 40$ magnification).

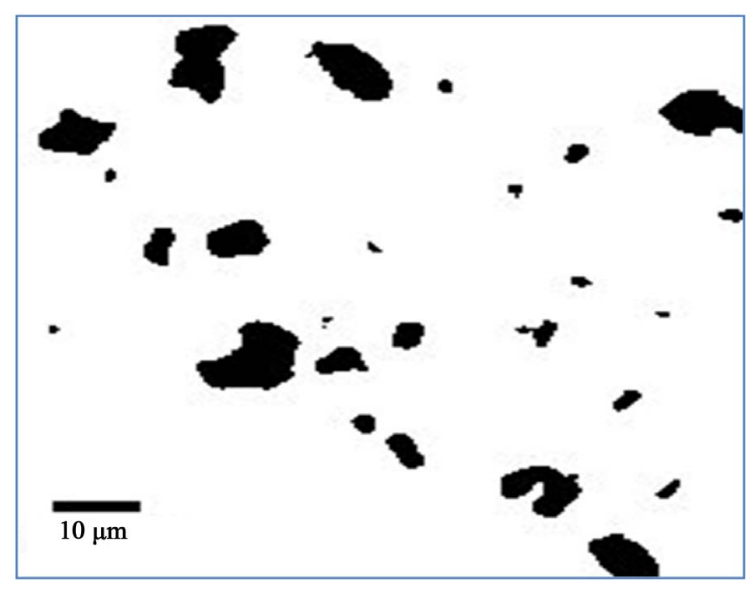

Figure 4. Optical microscope observation of roll milled pozzolana particles $(\times 40$ magnification $)$.

Table 1. Chemical composition of pozzolana and OPC.

\begin{tabular}{ccc}
\hline Constituent, \% & Pozzolana & OPC \\
\hline $\mathbf{S i O}_{2}$ & 62.03 & 19.70 \\
$\mathbf{A l}_{2} \mathbf{O}_{3}$ & 16.66 & 5.00 \\
$\mathbf{F e}_{2} \mathbf{O}_{3}$ & 12.98 & 3.16 \\
$\mathbf{C a O}$ & 0.21 & 63.03 \\
$\mathbf{M g O}$ & 1.75 & 1.75 \\
$\mathbf{S O} \mathbf{O}_{3}$ & 0.16 & 2.80 \\
$\mathbf{L O I}$ & 2.97 & 2.58 \\
Insoluble Residue & 47.24 & 2.98 \\
Mineralogy & & \\
$C_{3} S$ & & 61 \\
$C_{2} S$ & & 11 \\
$C_{3} \mathrm{~A}$ & & 10 \\
$C_{4} \mathrm{AF}$ & & \\
\hline
\end{tabular}




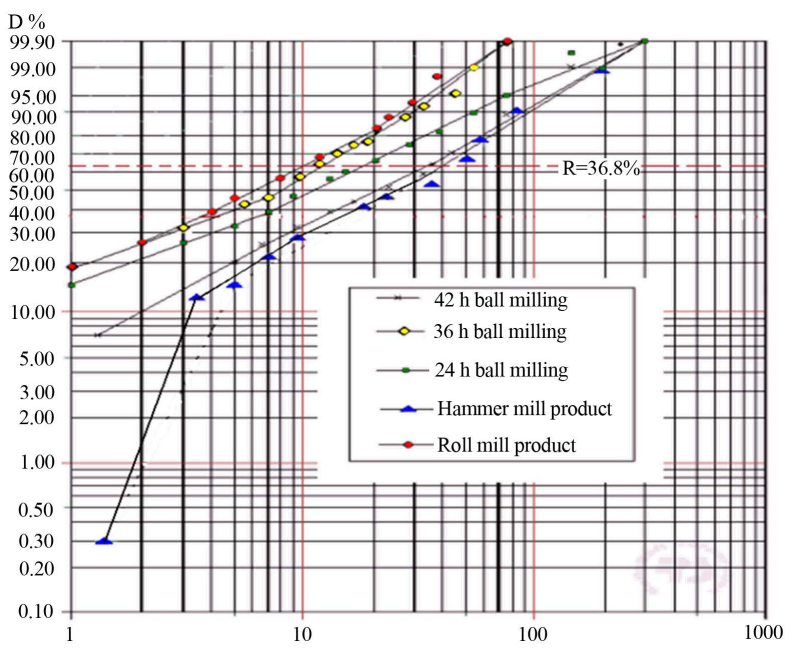

Figure 5. Rosin-Rammler distribution plot of mechanically activated pozzolana.

tribute to high reactivity of the roll milled as well as the $36 \mathrm{~h}$ ball milled products with OPC.

A Blaine index of $1025 \mathrm{~m}^{2} / \mathrm{kg}$ was achieved after $36 \mathrm{~h}$ ball milling. Agglomeration in the ball mill reduced the specific surface area and increased the characteristic particle size from $12 \mu \mathrm{m}$ to $38 \mu \mathrm{m}$ after $42 \mathrm{~h}$ of ball milling. Roll milling proved to be the most efficient means of size reduction, producing a characteristic particle size of 10 $\mu \mathrm{m}$ and a specific surface area determined by the Blaine method of $1123 \mathrm{~m}^{2} / \mathrm{kg}$. Hammer milling produced a specific surface area of $349 \mathrm{~m}^{2} / \mathrm{kg}$ as determined by the Blaine method.

\subsection{Compressive Strengths}

Figures 6-11 show the compressive strength development for the mechanically and chemically activated pozzolana cement mortar cubes at ages 2 to 90 days.

The compressive strength of the mechanically activated pozzolana cement mortar cubes increased faster after 28 days curing than that of OPC at all cement replacement levels, even though mortar cubes incorporating pozzolana were weaker. Increased fineness of the pozzolanas increased the compressive strength at all replacement levels. The highest compressive strengths at all test ages of the mechanically activated pozzolana cements were obtained by the roll milled pozzolana, followed closely by the $36 \mathrm{~h}$ ball milled pozzolana. The least strengths were obtained with hammer milling. Except for hammer milling, all the samples satisfied the EN 197-1 2-day compressive strength requirement of minimum $10 \mathrm{MPa}$ and the 7-day compressive strength requirement of $16 \mathrm{MPa}$ at all cement replacement levels tested.

Generally, compressive strengths of the chemically activated pozzolana cement mortars increased with in-

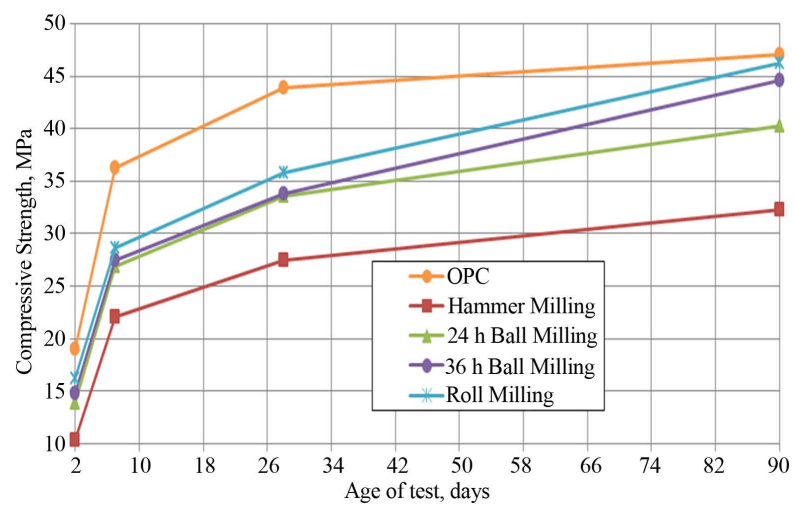

Figure 6. Compressive strength development of $30 \%$ mechanically activated pozzolana cement mortar cubes.

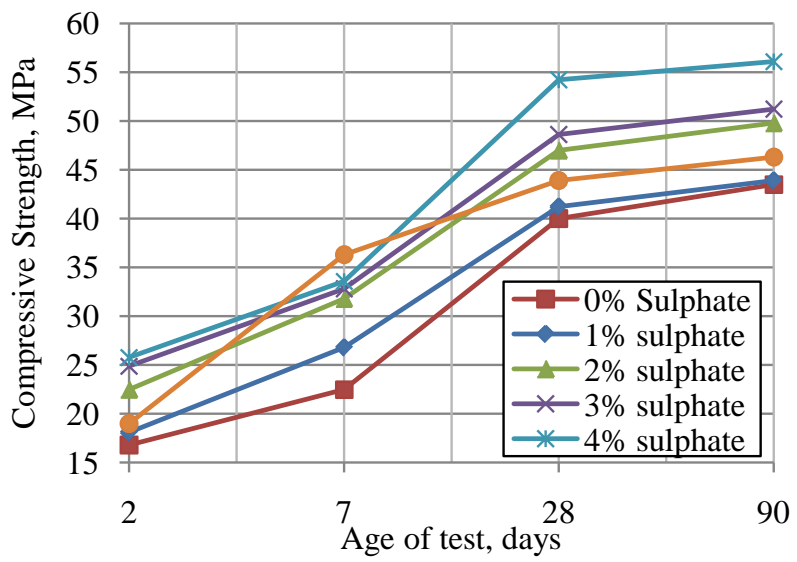

Figure 7. Compressive strength development of $30 \% \mathrm{Na}_{2} \mathrm{SO}_{4}$ activated pozzolana cement mortar cubes.

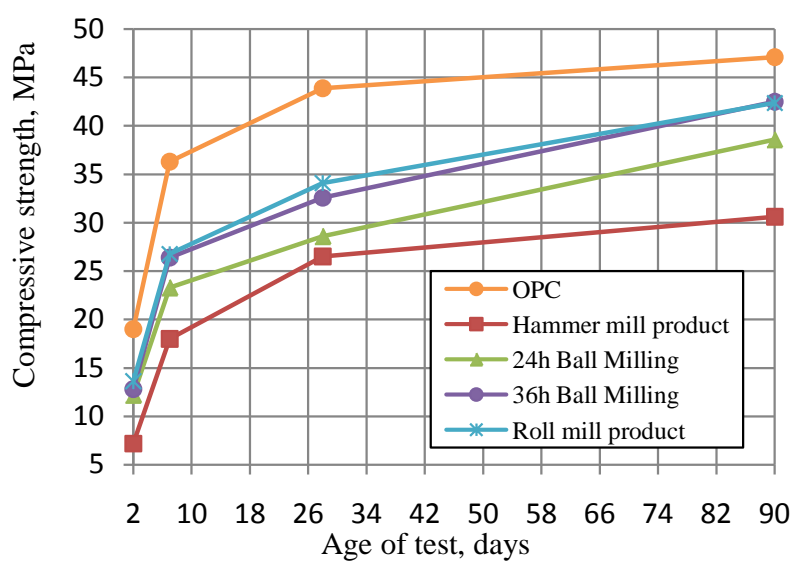

Figure 8. Compressive strength development of $35 \%$ mechanically activated pozzolana cement mortar cubes.

creasing $\mathrm{Na}_{2} \mathrm{SO}_{4}$ concentration. The highest compressive strengths at all test ages for the chemically activated pozzolana cement mortars were obtained at $4 \% \mathrm{Na}_{2} \mathrm{SO}_{4}$ concentration. Compressive strengths of the chemically activated pozzolana cement mortar cubes were higher than strengths of OPC at 2 days for $\mathrm{Na}_{2} \mathrm{SO}_{4}$ concentra- 


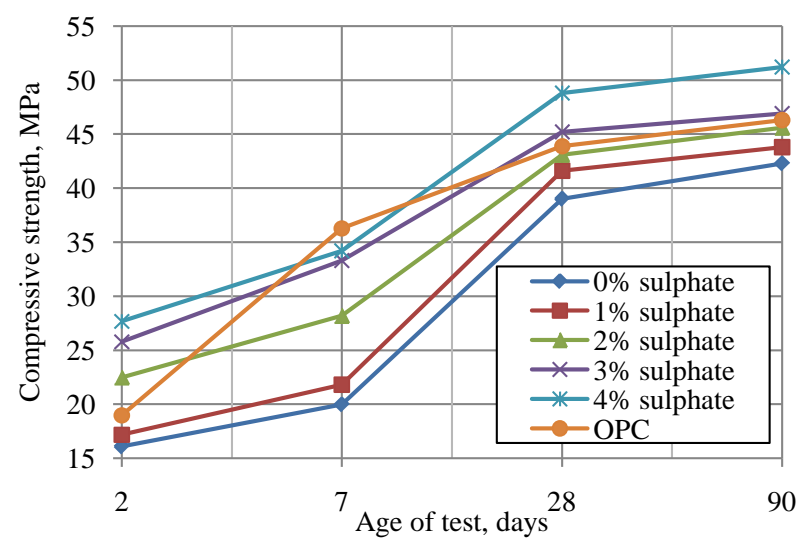

Figure 9. Compressive strength development of $35 \% \mathrm{Na}_{2} \mathrm{SO}_{4}^{-}$ activated pozzolana cement mortar cubes.

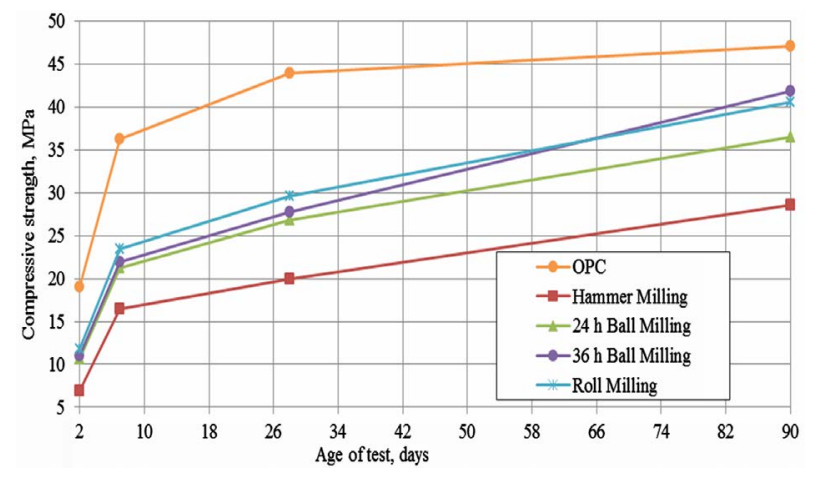

Figure 10. Compressive strength development of $40 \%$ mechanically activated pozzolana cement mortar cubes.

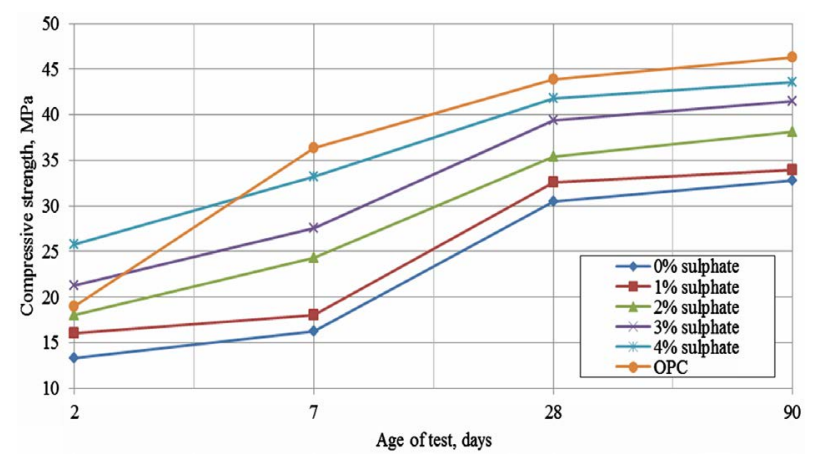

Figure 11. Compressive strength development of $40 \% \mathrm{Na}_{2} \mathrm{SO}_{4}$ activated pozzolana cement mortar cubes.

tions of $2 \%$ - $4 \%$ except at $40 \%$ cement replacement and passed the EN 197-1 standard of $10 \mathrm{MPa}$. However, lower compressive strengths were obtained compared to those of OPC for all sulphate concentrations tested at 7 days. Nevertheless, the EN 197-1 standard of $16 \mathrm{MPa}$ was satisfied. The ASTM C 595 minimum requirement of 24.1 MPa was also satisfied for all concentrations of $\mathrm{Na}_{2} \mathrm{SO}_{4}$ tested.

At 28 days, compressive strength of all activated pozzolana cement samples (both chemically and mechani- cally) satisfied EN $197-1$ at $30 \%$ pozzolana content. Pozzolana cement mortar cubes activated with 3\% - 4\% sulphate developed higher compressive strengths than OPC at $35 \%$ pozzolana content. At $40 \%$ pozzolana content, compressive strengths of the chemically activated pozzolanas were however lower than that of OPC. The ASTM C 595 requirement was satisfied at all replacement levels and sulphate concentrations.

The roll milled mechanically activated pozzolana cement mortar satisfied the EN 197-1 standard up to 35\% pozzolana content. The ASTM C 595 standard requirement on the other hand was satisfied by the mechanically activated pozzolana cement mortars at all replacement levels. 90-day compressive strengths attained satisfied the requirement of EN 197-1 up to 35\% pozzolana content for the roll milled and $36 \mathrm{~h}$ ball milled samples. Table 2 shows the compressive strength differences between the pozzolana cement mortars chemically activated with $4 \% \mathrm{Na}_{2} \mathrm{SO}_{4}(\mathrm{C})$ and the roll-milled mechanically activated (M) pozzolana cement mortar cubes for the different ages of test.

At equal ages of testing, higher early age compressive strengths were obtained by the chemically activated pozzolana cement mortar cubes than the mechanically activated pozzolana cement mortar cubes for all cement replacement levels tested. Compressive strength differences generally reduced as the curing period increased from 2 - 90 days. Early age strength differences (2 and 7 days) increased as pozzolana content increased. The 28 and 90 days compressive strength differences however decreased as pozzolana content increased.

The Rosin-Rammler distribution plots (Figure 5) show that the 24 hours ball milled pozzolana had about $50 \%$ material with particle size $\leq 11 \mu \mathrm{m}$. The presence of such large quantities of fine pozzolana particles contributed to the high 2 days compressive strength of the chemically activated pozzolana cement mortar cubes. At 2 days, the compressive strengths of the pozzolana cement activated with $2 \%-4 \% \mathrm{Na}_{2} \mathrm{SO}_{4}$ were higher than the strength attained by OPC except at $40 \%$ pozzolana content. As early as 2 days, Figure 12 shows a pozzolana particle being attacked by what is probably $\mathrm{NaOH}$ formed by reaction of $\mathrm{Na}_{2} \mathrm{SO}_{4}$ and $\mathrm{Ca}(\mathrm{OH})_{2}$. This highly basic environment will force the fine pozzolana particles into solution leading to the formation of afwillite and influencing higher early age strengths.

At 7 days most of the fine pozzolana particles had reacted leading to a sharp slump in the insoluble residue content (as shown in Figures 13-15) of the pozzolana cement paste and thus the lower compressive strengths compared to those of OPC.

The bulk of the insoluble residue content of the pozzolana cement paste is attributed to the pozzolana content of the paste since the insoluble residue of the Portland 
Table 2. Compressive strengths of $4 \% \mathrm{Na}_{2} \mathrm{SO}_{4}$ activated (C) and roll milled mechanically activated (M) pozzolana cement mortar cubes.

\begin{tabular}{|c|c|c|c|c|c|c|c|c|c|c|c|c|}
\hline \multirow{4}{*}{$\begin{array}{l}\text { Pozzolana } \\
\text { content,\% }\end{array}$} & \multicolumn{12}{|c|}{ AGE OF TEST, Days } \\
\hline & \multicolumn{4}{|c|}{2} & \multicolumn{2}{|c|}{7} & \multicolumn{3}{|c|}{28} & \multicolumn{3}{|c|}{90} \\
\hline & \multicolumn{12}{|c|}{ COMPRESSIVE STRENGTH, MPa } \\
\hline & C & M & Diff, \% & C & M & Diff, \% & C & M & Diff, \% & C & M & Diff, \% \\
\hline 30 & 28.5 & 16.2 & 43 & 33.6 & 28.6 & 24 & 54.2 & 35.8 & 34 & 56.1 & 46.3 & 18 \\
\hline 35 & 27.7 & 13.6 & 51 & 34.2 & 26.8 & 22 & 48.8 & 34.1 & 30 & 51.2 & 42.4 & 17 \\
\hline 40 & 25.8 & 11.8 & 54 & 33.2 & 23.4 & 30 & 41.8 & 29.6 & 29 & 43.6 & 40.6 & 1 \\
\hline
\end{tabular}

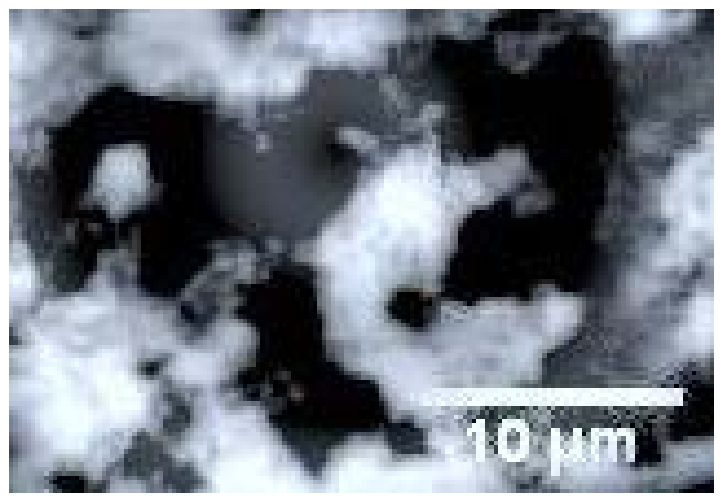

Figure 12. SEM image of $4 \% \mathrm{Na}_{2} \mathrm{SO}_{4}$ activated pozzolana cement paste containing $30 \%$ pozzolana at 2 days.

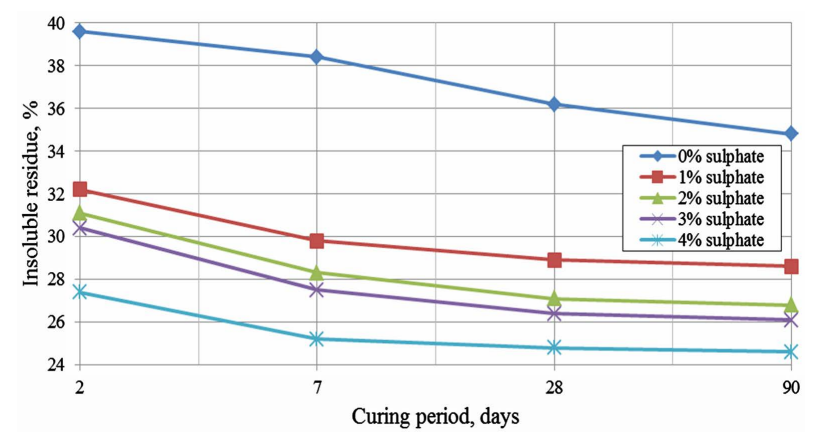

Figure 13. Insoluble residue in $\mathrm{HCl}$ of $\mathbf{3 0} \%$ chemically activated pozzolana cement paste.

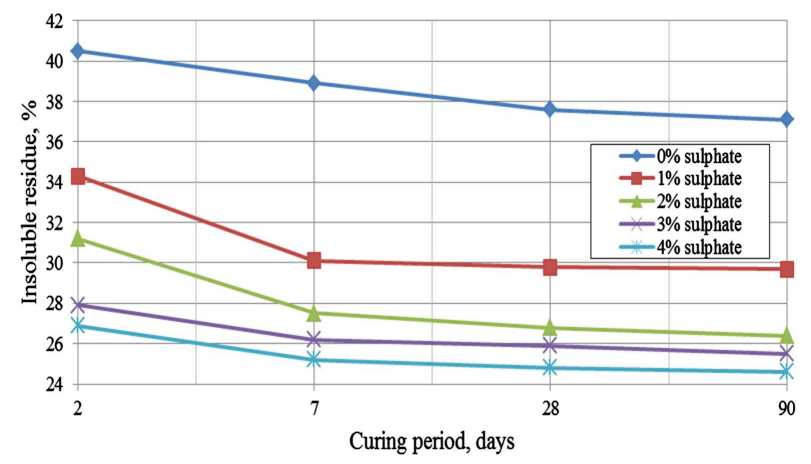

Figure 14. Insoluble residue in $\mathrm{HCl}$ of $35 \%$ chemically activated pozzolana cement paste.

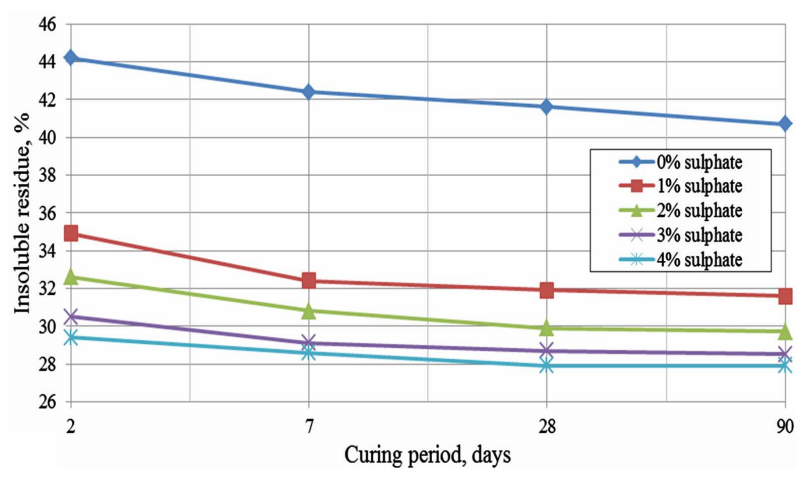

Figure 15 . Insoluble residue in $\mathbf{H C l}$ of $\mathbf{4 0} \%$ chemically activated pozzolana cement paste.

cement was less than 3\%. As pozzolana content increases, the insoluble residue decreases between 2 and 7 days (evidenced by an increase in range). A very sharp decrease in insoluble residue of the pozzolana-cement mixture is also observed between 2 days and 7 days of curing. This sharp decrease in insoluble residue content is attributed to the fine particles reacting with $\mathrm{Ca}(\mathrm{OH})_{2}$ in basic environment to form cementitious compounds. This improves on the strength of the alkali activated pozzolana cement as compared to the mechanically activated pozzolana cement. After 7 days curing, most of the fine pozzolana particles had reacted, causing a reduction in the reaction rate in the presence of alkali as evidenced in the flattening in the slopes of the insoluble residue curves and hence a decrease in the strength differences after 28 days as pozzolana content increased from 30\% - 40\%.

\subsection{Standard Consistence and Setting Times}

The standard consistence of the mechanically activated pozzolana cement is shown in Figure 16 whilst the initial and final setting times are shown in Figures 17 and 18. Data for the standard consistence and setting times of the chemically activated pozzolana cement are presented in Table 3.

Both the chemically and mechanically activated pozzolana cements required higher water content than OPC 
Table 3. Water demand and setting times of pozzolana cement paste activated with $\mathrm{Na}_{2} \mathrm{SO}_{4}$.

\begin{tabular}{cccccccccc}
\hline \multirow{2}{*}{$\begin{array}{c}\text { Activator } \\
\begin{array}{c}\text { concentration, } \\
\%\end{array}\end{array}$} & $\begin{array}{c}\text { Water } \\
\text { demand, } \\
\%\end{array}$ & $\begin{array}{c}\text { Initial } \\
\text { set, } \\
\text { min }\end{array}$ & $\begin{array}{c}\text { Final } \\
\text { set, } \\
\text { min }\end{array}$ & $\begin{array}{c}\text { Water } \\
\text { demand, } \\
\%\end{array}$ & $\begin{array}{c}\text { Initial } \\
\text { set, } \\
\text { min }\end{array}$ & $\begin{array}{c}\text { Final } \\
\text { set, } \\
\text { min }\end{array}$ & $\begin{array}{c}\text { Water } \\
\text { demand, } \\
\%\end{array}$ & $\begin{array}{c}\text { Initial } \\
\text { set, } \\
\text { min }\end{array}$ & $\begin{array}{c}\text { Final } \\
\text { set, } \\
\text { min }\end{array}$ \\
\hline 0 & 33.6 & 178 & 285 & 35.6 & 184 & 310 & 36.1 & 210 & 330 \\
1 & 33.6 & 162 & 240 & 35.6 & 178 & 255 & 36.1 & 202 & 290 \\
2 & 33.6 & 147 & 230 & 35.6 & 150 & 224 & 36.1 & 160 & 245 \\
3 & 33.6 & 131 & 203 & 35.6 & 130 & 200 & 36.1 & 142 & 221 \\
4 & 33.6 & 120 & 183 & 35.6 & 125 & 184 & 36.1 & 131 & 206 \\
\hline OPC & $\mathbf{2 8 . 2}$ & $\mathbf{1 8 5}$ & $\mathbf{2 8 0}$ & $\mathbf{2 8 . 2}$ & $\mathbf{1 8 5}$ & $\mathbf{2 8 0}$ & $\mathbf{2 8 . 2}$ & $\mathbf{1 8 5}$ & $\mathbf{2 8 0}$ \\
\hline
\end{tabular}

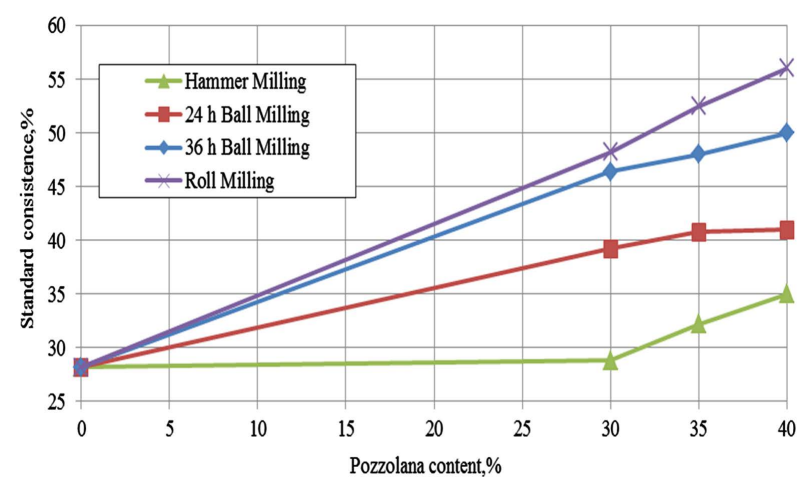

Figure 16. Standard consistence of mechanically activated pozzolana.

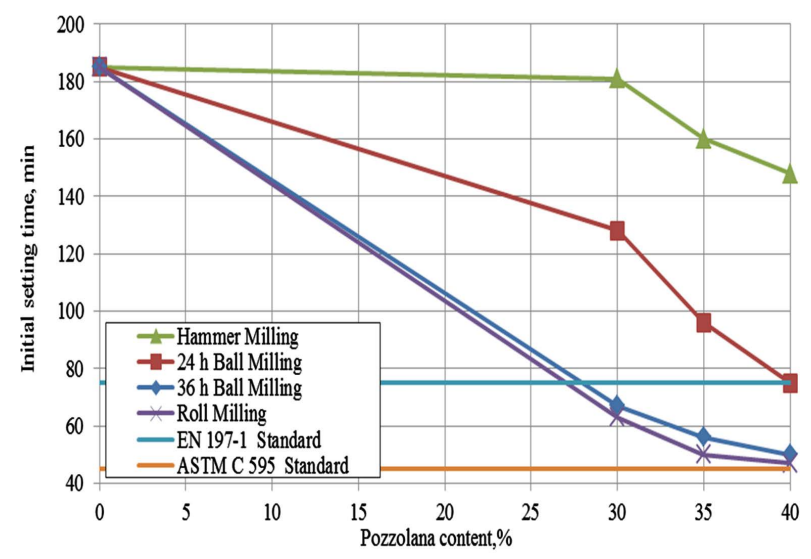

Figure 17. Initial setting time of mechanically activated pozzolana.

to form a workable paste. Standard consistence increased with increased pozzolana content for both types of activation. Similarly, standard consistence of the mechanically activated pozzolana increased as fineness increased. Increasing activator content however had no effect on standard consistence up to $4 \%$ concentration. Chemically activated pozzolana cement pastes had lower standard consistence compared to the mechanically activated

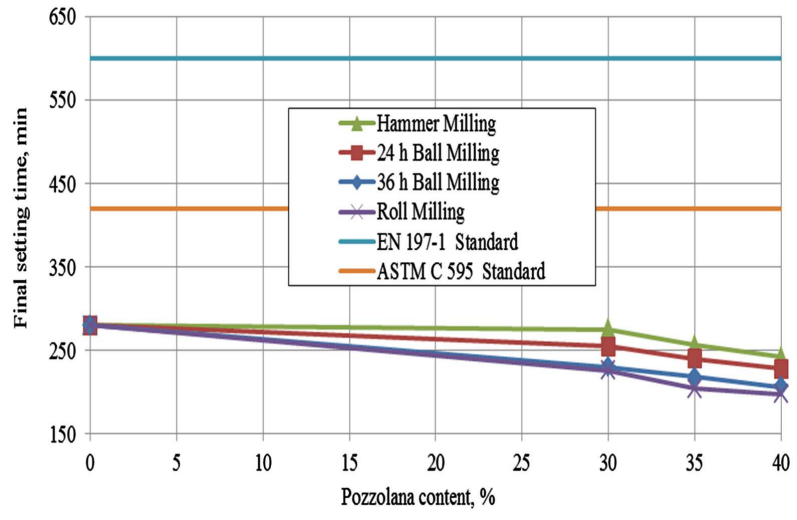

Figure 18. Final setting time of mechanically activated pozzolana.

pozzolana cement pastes at the same pozzolana content. The highest standard consistence, obtained for cement paste containing $40 \%$ roll milled pozzolana was $56 \%$ which was $27.8 \%$ higher than the OPC standard consistence.

\subsubsection{Initial Setting Time}

Initial setting time decreased with increasing fineness for the mechanically activated pozzolana cement and increasing activator concentration for the chemically activated pozzolana cement. In both cases of activation, initial setting times decreased as pozzolana content in the paste increased. The $36 \mathrm{~h}$ ball milled as well as the roll milled mechanically activated pozzolana cements failed to satisfy the EN 197-1 minimum standard at all pozzolana content up to $40 \%$. However they complied with the ASTM C 595 minimum standard of 45 min for pozzolana contents up to $40 \%$. The chemically activated pozzolana cement however complied with both EN 197-1 and ASTM C 595 standards for all pozzolana contents tested. The lower initial setting times at high fineness and higher activator concentrations indicate enhanced reactivity of the activated pozzolana cements upon hydration. 


\subsubsection{Final Setting Time}

Final setting times of the activated pozzolana cements satisfied both the EN 197-1 and ASTM C 595 standard requirements of $600 \mathrm{~min}$ and $420 \mathrm{~min}$ respectively. As with the initial setting times, final setting times of the chemically activated pozzolana cement pastes decreased as $\mathrm{Na}_{2} \mathrm{SO}_{4}$ concentration increased from $1 \%-4 \%$. Figure 18 also shows that the mechanically activated pozzolana cements attained final sets faster as fineness increased and as pozzolana content increased up to $40 \%$. The final setting times of both chemically and mechanically activated pastes were mostly lower than that obtained for OPC.

\section{Conclusions}

The clay pozzolana samples used for this work contained adequate amounts of reactive silica and alumina, obtaining silica content above the minimum limit of $25 \%$ as required by EN 197-1. The sum of the $\mathrm{SiO}_{2}, \mathrm{Al}_{2} \mathrm{O}_{3}$ and $\mathrm{Fe}_{2} \mathrm{O}_{3}$ content of the pozzolana was above the ASTM C 618 minimum standard of $70 \%$. Activation of the pozzolana sample was achieved by the addition of between $2 \%-4 \% \mathrm{Na}_{2} \mathrm{SO}_{4}$; by roll milling and after $36 \mathrm{~h}$ of ball milling beyond which agglomeration prevented activation. The minimum concentration of $\mathrm{Na}_{2} \mathrm{SO}_{4}$ for chemical activation was $2 \%$. Roll milling with classification offered the most effective means of mechanical activation of the pozzolanas. Particle sizes attained by roll milling and ball milling were typically in the micrometer range with a characteristic particle size of $9 \mu \mathrm{m}$ after roll milling. Standard consistency of the activated pozzolanas progressively increased with increasing pozzolana content. The water demand of the pozzolana cement remained unchanged at all $\mathrm{Na}_{2} \mathrm{SO}_{4}$ concentration levels. Increasing fineness and $\mathrm{Na}_{2} \mathrm{SO}_{4}$ concentration resulted in decrease in both initial and final setting times.The setting times and standard consistencies of the pozzolana cement samples were all within acceptable limits per EN 197-1 and ASTM C 595 standards.

Compressive strengths (2, 7 and 28 days) of pozzolana cement mortar cubes decreased with increasing pozzolana content up to $40 \%$. The addition of $\mathrm{Na}_{2} \mathrm{SO}_{4}$ significantly improved both early and ultimate strengths of the pozzolana cement studied. The 2 day strength for $30 \%$ and $35 \%$ pozzolana cement were improved by $25.3 \%$ and $18.4 \%$ respectively. Lower 2-day compressive strengths were recorded for the mechanically activated pozzolanas than OPC although strength values exceeded the EN 197-1 and ASTM C 595 standard requirements. At 28 days, the compressive strength of the control was exceeded at $\mathrm{Na}_{2} \mathrm{SO}_{4}$ concentrations $\geq 2 \%$. Roll milling gave the highest 28-day compressive strengths for the mechanical activation methods investigated with strengths of 35.8 MPa at 30\% pozzolana content and 29.6 MPa at
$40 \%$ pozzolana content. These strengths both passed the ASTM C 595 minimum strength of 24.1 MPa. After $36 \mathrm{~h}$ ball milling, the activated pozzolanas could be used to replace $30 \%-40 \%$ OPC with a 28-day compressive strength of $27.7 \mathrm{MPa}$ at $40 \%$ pozzolana content. The activated pozzolanas could thus be used successfully to replace up to $40 \%$ OPC for most non-load bearing housing construction purposes.

\section{REFERENCES}

[1] Global Cement, Report of the 2009 International Cement Review Committee, New York, 2010.

[2] P. Claus and M. Guimaraes, "The $\mathrm{CO}_{2}$ Uptake of Concrete in a 100 Year Perspective," Cement and Concrete Research, Vol. 37, No. 9, 2007, pp. 1348-1356. http://dx.doi.org/10.1016/j.cemconres.2007.06.009

[3] K. L. Scrivener and R. J. K. Patrick, "Innovation in Use and Research on Cementitious Material," 12th International Congress of Chemistry of Cement, Montreal, 8-13 July 2007.

[4] D. X. Li, Y. M. Chen, L. S. Jin, H. S. Jiao and X. Q. Wu, "The Influence of Alkalinity on Activation and Microstructure of Fly Ash,” Cement and Concrete Research, Vol. 30, No. 6, 2000, pp. 881-886.

http://dx.doi.org/10.1016/j.cemconres.2007.06.009

[5] C. Shi and Y. Shao, "What is the Most Efficient Way to Activate the Reactivity of Fly Ashes?” 2nd Material Specialty Conference of Canadian Society for Civil Engineering, Montréal, 5-8 June 2002, 10 p.

[6] F. M. Lea, "The Chemistry of Cement and Concrete," 4th Edition, Elsevier (Publishers) Ltd., Glasgow, 1998, p. 263.

[7] Ghana Standards GS 803, "Specification for PozzolanaCalcined Clay Based,” Ghana Standards Authority, Accra, 2009, pp. 1-20.

[8] European Standard EN 197-1, "Composition, Specifications and Conformity Criteria for Common Cements," European Committee for Standardization, Brussels, 2000, p. 15.

[9] American Society for Testing and Materials, “2000 Annual Book of ASTM standards: Part 14-C 595; Specification for Blended Hydraulic Cement,” ASTM, Philadelphia, 2000, pp. 337-345.

[10] American Society for Testing and Materials,"2000 Annual Book of ASTM standards: Part 14-C 618; Standard Specification for Fly Ash and Raw or Calcined Natural Pozzolana for Use as a Mineral Admixture in Portland Cement Concrete,” ASTM, Philadelphia, 2000, pp. 355358.

[11] Indian Standard IS 1489-1, "Portland-Pozzolana Cement: Specification,” Bureau of Indian Standards, New Delhi, 1991, pp. 1-12.

[12] C. Shi and R. L. Day, "Acceleration of Strength Gain of Lime-Pozzolan Cement Pastes by Thermal Activation,” Cement and Concrete Research, Vol. 23, No. 4, 1993, pp. 824-832. 
http://dx.doi.org/10.1016/j.cemconres.2007.06.009

[13] C. Shi and R. L. Day, "Acceleration of the Reactivity of Fly Ash by Chemical Activation," Cement and Concrete Research, Vol. 25, 1, No. 1995, pp. 15-21. http://dx.doi.org/10.1016/0008-8846(94)00107-A

[14] R. L. Day and C. Shi, "Correlation between the Strength Development of Lime-Natural Pozzolan Cement Pastes and the Fineness of Natural Pozzolan," Cement and Concrete Research, Vol. 24, No. 8, pp. 1485-1491. http://dx.doi.org/10.1016/0008-8846(94)90162-7

[15] M. Oriol and J. Pera, "Pozzolanic Activity of Metakaolin under Microwave Treatment," Cement and Concrete Research, Vol. 25, No. 2, pp. 265-270. http://dx.doi.org/10.1016/0008-8846(95)00007-0

[16] C. Shi, "An Overview on the Activation of Reactivity of Natural Pozzolans," Canadian Journal of Civil Engineering, Vol. 28, No. 5, pp. 778-786. http://dx.doi.org/10.1139/101-041

[17] B. Aldemir, "Parameter Optimization of Chemically Activated Mortars Containing High Volume Pozzolan by Statistical Design and Analysis of Experiments,” A Thesis Submitted to the Graduate School of Natural and Applied Sciences, Middle East Technical School, Ankara, 2006, pp. 7-8.

[18] C. Shi and R. L. Day, "Comparison of Different Methods for Enhancing Reactivity of Pozzolans," Cement and Concrete Research, Vol. 31, No. 5, 2001, pp. 813-818. http://dx.doi.org/10.1016/S0008-8846(01)00481-1

[19] Y. M. Fan, S. H. Yin, Z Y. Wen and J. Y. Zhong, “Activation of Fly Ash and Its Effects on Cement Properties," Cement and Concrete Research, Vol. 29, No. 4, 1999, pp. 467-472. http://dx.doi.org/10.1016/S0008-8846(98)00178-1

[20] A. Palomo, M. W. Grutzeck and M. T. Blanco, "Alkali Activated Fly Ashes-Cement for the Future,” Cement and Concrete Research, Vol. 29, No. 8, 1999, pp. 1323-1329. http://dx.doi.org/10.1016/S0008-8846(98)00243-9

[21] K. J. Owens, Y. Bai, D. Cleland, P. A. M. Basheer, J. Kwasny, M. Sonebi, S. Taylor and A. Gupta, “Activation of High Volume Fly Ash Paste Using Chemical Activators," 2nd International Conference on Sustainable Construction Materials and Technologies, Universita Politecnica Delle Marche, Ancona, 28-30 June 2010, pp. 1759-
1770.

[22] M. A. Glinicki, "Application of Activated Fly Ash from Fluidised Boilers as an Additive to Concrete," Conference Paper Presented to the Power Industry and Environment Protection Conference, ECOENERGIA-2002, Warsaw, 7-9 May 2002, pp. 108-116.

[23] B. Uzal and L. Turanli, "Studies on Blended Cements Containing a High Volume of Natural Pozzolans,” Cement and Concrete Research, Vol. 3, No. 11, 2003, pp. 1777-1781. http://dx.doi.org/10.1016/S0008-8846(03)00173-X

[24] A. Naceri and M. Benia, "The Effect of Fineness of Cements with Mineral Admixtures on the Mechanical Response of Concrete,” Asian Journal of Civil Engineering, Vol. 7, No. 3, 2006, pp. 239-248.

[25] E. Atiemo, "Clay as Pozzolana for Building Purposes," Journal of Building and Road Research, Vol. 2, No. 1-2, 1998, p. 10.

[26] E. Atiemo, "Production of Pozzolana from Some Local Clays: Prospects for Application in Housing Construction,” Journal of Building and Road Research, Vol. 9, No. 1-2, 2005, p. 34

[27] British Standards 1377, "Part 2; Methods of Test for Soils for Civil Engineering Purposes-Classification Tests,” BSI, London, 1990, p. 42.

[28] American Society for Testing and Materials, "2000 Annual Book of ASTM standards: Part 13-C 204; Standard Test Method for Fineness of Portland Cement by Air Permeability Method,” ASTM, Philadelphia, 2000, pp. 195-201.

[29] European Standard EN 196-1, "Methods of Testing Cement: Determination of Strength,” European Committee for Standardization, Brussels, 2000, pp. 1-36.

[30] European Standard EN 196-2, "Methods of Testing Cement: Chemical analysis of cement," European Committee for Standardization, Brussels, 2000, pp. 1-16.

[31] European Standard EN 196-3, "Methods of Testing Cement: Determination of Setting Times and Soundness," European Committee for Standardization, Brussels, 2000, pp. 1-18. 